\title{
HOW MIDDLE MANAGERS CONTRIBUTE TO STRATEGY FORMATION PROCESS: CONNECTION OF STRATEGY PROCESSES AND STRATEGY PRACTICES
}

COMO GERENTES DE NÍVEL MÉDIO CONTRIBUEM PARA O PROCESSO DE FORMAÇÃO DE ESTRATÉGIA: CONEXÃO ENTRE PROCESSOS ESTRATÉGICOS E PRÁTICAS ESTRATÉGICAS

CÓMO GERENTES DE NIVEL MEDIO CONTRIBUYEN AL PROCESO DE FORMACIÓN DE ESTRATEGIA: CONEXIÓN ENTRE PROCESOS ESTRATÉGICOS Y PRÁCTICAS ESTRATÉGICAS

\section{ABSTRACT}

The role of middle management is essential when managing integrative and emergent strategy formation processes. We stand out the importance of its role connecting micro and macro organizational level offering a very important contribution when examining the strategy-as-practice perspective and integrative strategy formation process. The main goal of this research is to analyse the relationship between the integrative strategy formation process and the roles of middle management under the strategy-as-practice perspective. To check it out we adopted a qualitative methodology droving a case analysis in a Spanish University. Data was collected by means of personal interviews with members of different levels of the Institution, documents analysis and direct observation. In advance of some results we find out that the University develops an integrative strategy formation process and confers to middle management an important role extended all over the organization.

KEYWORDS Middle management, strategy formation process, strategy-as-practice, case study, strategizing.

Rosalia Aldraci Barbosa Lavarda rlavarda@furb.br

Doctora en Dirección de Empresas, Estrategias y Organización por la Universitat de València - València, España

María Teresa Canet-Giner teresa.canet@uv.es

Doctor en Economía y Dirección de Empresas, Estrategias y Organización por la Universitat de València - València, España

Fernando Juan Peris-Bonet fernando.peris@uv.es

Doctora en Economía y Dirección de Empresas, Estrategias y Organización por la Universitat de València - València, España

Recebido em 27.08.2009. Aprovado em 12.07.2010

Avaliado pelo sistema double blind review

Editor Científico: Sérgio Bulgacov

RESUMO O papel do nível médio de administração é essencial quando se trata de uma gestão com processo integrador e emergente de formação da estratégia. Salientamos a importância do papel deste nível intermediário que deve conectar de forma ajustada o nível micro e macro-organizacional, oferecendo uma contribuição importante quando se examina a perspectiva da estratégia-como-prática e o processo integrador de formação da estratégia. O principal objetivo desta pesquisa é analisar a relação entre o processo integrador de formação da estratégia e os papéis do middle manager sob a perspectiva da estratégia-como-prática. Adotamos uma metodologia qualitativa por meio do estudo de caso em uma Universidade espanhola. Os dados foram coletados por meio de entrevistas em profundidade, análise de documentos e observação direta. Encontramos que a Universidade desenvolve um processo integrador de formação da estratégia e confere ao nível intermediário um importante papel que é estendido a toda a organização.

PALAVRAS-CHAVE Middle manager, processo-integrador-de-formação-da-estratégia, estratégia-como-prática, estudo de caso, strategizing.

RESUMEN El papel del nivel medio de administración es esencial cuando se trata de una gestión con proceso integrador y emergente de formación de la estrategia. Resaltamos la importancia del papel de este nivel intermedio que debe conectar de forma precisa los niveles micro y macroorganizacional, ofreciendo una contribución importante cuando se examina la perspectiva de la estrategia como práctica y el proceso integrador de formación de la estrategia. El principal objetivo de esta investigación es analizar la relación entre el proceso integrador de formación de la estrategia y los papeles del middle manager bajo la perspectiva de la estrategia como práctica. Adoptamos una metodología cualitativa a través del estudio de caso en una universidad española. Los datos fueron recolectados a través de entrevistas en profundidad, análisis de documentos y observación directa. Encontramos que la universidad desarrolla un proceso integrador de formación de la estrategia y le confiere al nivel intermedio un importante papel que se extiende a toda la organización.

PALABRAS CLAVE Middle manager, proceso integrador de formación de la estrategia, estrategia como práctica, estudio de caso, strategizing. 


\section{INTRODUCTION}

The change and the growing dynamism of the environment lead organizations to a strategy formation process requiring the involvement of all the organization hierarchical levels forcing the evolution of the top-down perspective towards a more bottom-up one-considered under a microorganizational perspective that sets the emphasis in the process- or towards a middle-up-down perspective. Around these perspectives we can find different studies focused on the emergence of the strategy based on the middle manager role and their involvement in the strategic process (FLOYD and WOOLDRIDGE, 1992, 2000; FLOYD and LANE, 2000; NONAKA, 1988; WOOLDRIDGE and FLOYD, 1990; BALOGUN, 2003).

On the other hand, the practice perspective suggests that organizations are brought into being through the organizing activities and practices of actors in interaction with one another (SCHATZKI, 2005; WHITTINGTON, MOLLOY, MAYER and SMITH, 2006).

For that purpose, we analyse literature on strategy formation process; adopting an integrative approach in the analysis of the strategic process (MINTZBERG, 1973; MINTZBERG and WATERS, 1985; HART, 1992; BREWS and HUNT, 1999; ANDERSEN, 2000, 2004a, 2004b); and we consider strategy-as-practice studies (JARZABKOWSKI, 2003 and 2008; JARZABKOWSKI and FENTON, 2006; JARZABKOWSKI, BALOGUN and SEIDL, 2007) that are being intensely developed considering the middle management roles and characteristics, as well as their relationship with the level of involvement in the firm, under this practice perspective.

Thus, our goal in this research is to analyse the relationship between the integrative strategy formation process and the roles of middle management under the strategyas-practice perspective.

Hence, our research questions are the following:

Q1: How does the strategy formation process take place; particularly, considering the relevance of the integrative perspective and the use of the variables -- rationality, involvement, and vision?

Q2: Which is the relationship between an integrative strategy formation process and the middle management roles? Q3: How is the strategy-as-practice approach related to the strategic variables (rationality, involvement and vision) and with the different roles of middle management?

We go over the different arguments on strategy formation process, and study the variables that define this process (MINTZBERG and WATERS, 1985; HART, 1992; ANDERSEN, 2004a and b) to answer these questions. Furthermore we consider the roles of middle management (FLOYD and WOOLDRIDGE, 1992, 1994, 1997, 2000; FLOYD and LANE, 2000; NONAKA, 1988; WOOLDRIDGE and FLOYD, 1990; BALOGUN, 2003, MANTERE, 2008) and the studies of the strategy-aspractice perspective (JARZABKOWSKI, 2003, 2008; JARZABKOWSKI and FENTON, 2006; JARZABKOWSKI and WHITTINGTON, 2007, 2008; JARZABKOWSKI, BALOGUN and SEIDL, 2007; JARZABKOWSKI and SEIDL, 2008, JARZABKOWSKI and SPEE, 2009) considering that middle management is in charge of implementing strategy practices.

After reviewing the theory we formulate different propositions highlighting that an integrative strategy formation process that combines with certain equilibrium rationality and emergence facilitates a more effective management of work, considering specifically the roles played by middle manager as a facilitator of this process, mainly in a dynamic environment from a strategy-aspractice perspective.

To achieve the goal proposed, that is, the study of how the processes take place, we adopted a qualitative methodology (YIN, 1993), specifically a case analysis, studying how the strategy formation process develops (JARZABKOWSKI and WILSON, 2002; JOHNSON, MELIN and WITTINGTON, 2003:11; REGNÉR, 2003; JARZABKOWSKI, 2003; JARZABKOWSKI et al, 2007).

\section{AN INTEGRATIVE STRATEGY FORMATION PROCESS}

Our research focuses on the study of the integrative approach, a balance between a rational and planned strategy (ANSOFF, 1965; PORTER, 1980) and an emergent one (MINTZBERG, 1973; QUINN, 1978; FARJOUN, 2002) when analysing the strategy formation process. This integrative approach is present in the works of Mintzberg and Waters (1985); Hart (1992); Hamel and Prahalad (1994) and also in more recent contributions as the works of Johnson, et al. (2003); Andersen (2000, 2004a, 2004b) or Elbanna (2006).

From this integrative perspective, different authors as Johnson et al. (2003) try to analyse the organization starting from the study of those activities that take place in the firm. They assume that the analysis of the strategy formation process can be better developed through the analysis of the different activities and types of work that take place in the organization. Consequently, from this 
perspective the strategy should emerge from the microorganizational level, where the task development takes place. Thetask level is where attitudes, relationships, and actions are generated. These authors consider that focusing on this micro-level perspective the organization can achieve important benefits; that is, when the environment is very turbulent (competitive, dynamic and complex) more people are more frequently involved in the strategy formation process, and greater levels of decentralisation would be required if the firm wants that its strategic approach obtains good results.

The work of Elbanna (2006) also indicates that the strategy formation process must follow an integrative pattern, with a balance between emergent issues and the required rational focus. The author acknowledges that significant initiatives can come from inside the organization.

Andersen (2004a, 2004b) stands the relevance of the dynamic interaction between emergence and planning. In our research we must draw the attention to the concept of decentralised strategy formation process (following ANDERSEN, 2004b); this is a process that facilitates the emergence of different strategic contributions that come from those managers belonging to the lowest levels of the organization (bottom-up influence) (ANDERSEN, 2004b:1274). This author emphasises also the concept of strategic planning and the need of analysis when firms have to adopt a strategic decision (top-down influence).

Hence, we can affirm that an integrative strategy formation process is the one that considers jointly the need of a decentralised strategic process and the need of a strategic planned process (ANDERSEN, 2004b:1276).

When we refer to the planning process, the most important variable is rationality. A rational process is an analytical one, with a certain degree of formalisation (ANSOFF, 1987). On the other hand, we highlight the concept of emergence (from a bottom-up perspective). This concept considers that strategy must not be imposed from the top; and that strategy can emerge (strategic initiatives) as a consequence of working in groups. So that, the most relevant concept in this framework is the concept of involvement (his variable has been used in less studies on strategy formation process (SHRIVASTAVA and GRANT (1985); NONAKA (1988); WOOLDRIDGE and FLOYD (1990); HART (1992)) However, more recent works show the significance of the variable involvement in the strategy formation process and its effect on performance (COLLIER, FISHWICK and FLOYD, 2004; CURRIE and PROCTER, 2005) or point it indirectly out through the active participation of middle managers in the daily work processes related to the strategy formation (CURRIE and PROCTER, 2005; JOHNSON et al, 2003; ROULEAU, 2005:1438). Furthermore, the inductive model presented by Regnér (2003:78) or the strategic role of the middle manager in the classification of Floyd and Lane (2000) assume the existence of an important degree of involvement of lower levels managers.

If both, rationality and emergence must reach a coherent fit, they need to be integrated. The umbrella that integrates both variables is vision (WEICK, 1989, HART, 1992; MINTZBERG and WATERS, 1985 when they talk about ideological or umbrella processes, and HAMEL and PRAHALAD, 1994 when defining the "strategic intent" and the concept of "strategic architecture"). When there is a clear vision that is communicated; when the objectives and mission are explicit; and when the leader is able to communicate and transmit them, then the initiatives have a common goal, they emerge in a certain order, influenced by the rational and planned processes.

\section{DECISION-MAKING PROCESS AND THE ROLES OF MIDDLE MANAGEMENT}

We consider here the different perspectives of taking decision processes (top-down, middle-up-down and bottom-up) that put the emphasis in the role and in the directive figure (NONAKA, 1988, 1994) and that are in a straight line with the different processes of strategy formation, focusing on the bottom-up and middle-updown perspectives [which we consider that is related to the strategy-as-practice perspective (JARZABKOWSKI et al, 2007)].

Such as Burgelman outlines (1983a), the strategy formation process would be that one able to combine the two extreme models, one analytic and planned and the second one creative and emergent formed in the lowest levels of the firm and based on the individual initiative. Thus, mainly when the organization manages products, services or complex work, strategy is characterized as a social construction activity (HENDRY, 2000) where, consequently, the actors at all levels have helped in the process of forming the strategy. This reasoning has been largely accepted and confirmed by different recent studies (FLOYD and LANE, 2000; FARJOUN, 2002; HICKSON, MILLER and WILSON, 2003; JARZABKOWSKI, 2003; REGNÉR, 2003; COLLIER, FISHWICK and FLOYD, 2004; ANDERSEN, 2004a, 2004b; CURRIE and PROCTER, 2005; ROULEAU, 2005; ELBANNA, 2006, MASON, 2007; PAPPAS and WOOLDRIDGE, 2007). 
According to Nonaka (1988 and 1994), top-down management is formed by top managers, with independent leaders who allocate resources hierarchically; motivation comes from extrinsic incentives and the emphasis is put on the explicit knowledge (standards and rules that define the tasks); those characteristics lead to a heavy reliance on top management. In contrast, middle-up-down management is composed of middle managers acting as coordinators and facilitators of the process and catalysts leading to the creation of organizational knowledge, which allocate resources from different points of view and focus on knowledge, which can be explicit and tacit (experience). On the other hand, bottom-up management, is made up with employees who act as entrepreneurs and leaders that create or sponsor various projects and information.

While research in strategy are primarily focused on top-down decision making models, based on prescription and deduction, another theoretical perspective begins to emerge in the literature. The "emergent" vision in contrast to the "deliberate" vision has been rising as an alternative perspective on the strategy formation process (MINTZBERG and WATERS, 1985; BURGELMAN, 1983a, 1983b, 1991, 1996, 2002; MASON, 2007). The emerging view, however, does not seek to impose that top management must be out of control of the strategic decisions of the company. It maintains the notion that top management should retain the authority to make strategic decisions, but should be open, receptive, and respond to any new information that may arise from other actors in the organization (MINTZBERG and WATERS, 1985:271), who think and act and should be recognized within the decision-making process because their initiatives have strategic implications (FLOYD and WOOLDRIDGE, 2000).

Moreover, bottom-up perspective, considered entrepreneurial, democratic, with horizontal hierarchical structure based on people and tacit knowledge (BURGELMAN, 1983a, 1991, 1996 and 2002), has been called to answer to the complexity [(defined as the diversity and heterogeneity of the environment and its socio-political, technological system; customers and suppliers) (LANE and MAXFIELD, 1996)] and the turbulence of the environment (defined as dynamism in the environment, involving rapid and unexpected changes in the sub-dimensions of the environment) (MASON, 2007).

Thus, top-down perspectives, autocratic, with high hierarchies, with a focus on explicit knowledge and decisions from above (HAMBRICK, 1981, 1987 and HAMBRICK and MASON, 1984) and bottom-up perspective, entrepreneur, democratic, with horizontal hierarchical structure based on people and tacit knowledge
(BURGELMAN, 1996 and 2002), clarify and give way to a third perspective: the middle-up-down, with middle managers acting as coordinators, hierarchies based in branches groups and groups oriented by entrepreneur employees, and focusing simultaneously on the explicit and tacit knowledge, with a common vision and objectives guiding the activity, and autonomy to develop this activity (NONAKA, 1988 AND 1994, HAMEL and PRAHALAD, 1994; FLOYD and WOOLDRIDGE, 1994 1997, and 2000).

From the studies of Burgelman (1983a, 1983b and 1996), Nonaka (1988, 1994), Floyd and Wooldridge (1992, 1994, 1997, and 2000); Wooldridge and Floyd (1990), Floyd and Lane (2000), Currie and Procter (2005) and Rouleau (2005) who argues that the performance is heavily influenced by what happens in the middle level of the organization, we highlight the contribution and influence of middle managers in the strategy formation process and the concept of strategy-as-practice (JARZABKOWSKI, 2008) as an approach that is suitable.

Regarding to middle managers, their role is important in all levels. However, the middle-up-down model is where the manager role generates a continuous integration of information flows, has major importance and it is necessary and essential for performance. In other cases (top-down and bottom-up), it acts as transmitting information; the role is important but does not act so absolutely in a key way.

According to Floyd and Lane (2000:159) in the decision-making process top managers exercised the strategic role of ratifying (presenting the strategic intentions, controlling, approving and sustaining); recognizing (recognizing the strategic potential, establishing strategic guidelines, strengthing and facilitating processes) and directing (planning, providing resources and sending resources). Middle managers communicate and transmit information from the bottom to the top level, exercising the role of defender (championing alternatives, guiding and promoting, defending, presenting alternatives to top management); synthesizer (categorizing ideas, selling these ideas to top management, combining and applying the information, synthesising it); and from the top level to bottom as facilitator (protecting and promoting adaptation activities, sharing information, guiding the adaptation, facilitating learning and adaptability); and implementer (implementing deliberate strategy, reviewing and adjusting, motivating and inspiring as a coach). And bottom level play a central role, reacting to the information that comes from different areas: (i) products in the market (trying on, learning and connecting to improve techni- 
cal abilities and needs, starting initiatives and assuming risks), (ii) from top managers (in obedience, following the system), (iii) and/or trying to react when the information comes from the two sides, adjusting intentions (responding to the challenge).

As stated before, the middle manager acts as synthesizer and as facilitator, promoting the adaptation and continuous flow of information and participation, which facilitates the link among the different and necessary works developed in the organization. And also, in its role of developer, facilitates, motivates and adjusts the process of implementing the strategic plans, allowing the participation and involvement and contributing to the inspiration of the actors that at any time may propose issues or suggestions that lead to modify the plan or its implementation.

\section{STRATEGY-AS-PRACTICE APPROACH OR STRATEGIZING}

Considering the studies of strategy-as-practice perspective (JARZABKOWSKI, 2003; JARZABKOWSKI and FENTON, 2006; JARZABKOWSKI, BALOGUN and SEIDL, 2007; JARZABKOWSKI and WHITTINGTON, 2007, 2008; JARZABKOWSKI and SEIDL, 2008, JARZABKOWSKI and SPEE, 2009) we ought to agree that a new perspective, a new approach is gaining authority and it is tough sustained with empirical researches (ROULEAU, 2005; JARZABKOWSKI and SILLINCE, 2007; BALOGUN and SEIDL, 2007: REGNÉR, 2008) not just in Europe but in the Academy of Management publications and in HEC Montreal researches (ROULEAU 2003, 2005).

Two important conceptual orientations are offered by Jarzabkowski et al. (2007:7) informing different aspects of strategy-as-practice, which we borrow to review and sinthesize this form of understanding strategy.

From this perspective, strategy is conceptualized as a situated, socially accomplished activity, while strategising comprises those actions, interactions and negotiations of multiple actors and the situated practices that they draw upon in accomplishing that activity (JARZABKOWSKI, 2003).This is a broad definition as it encompasses all types of social activity; as the authors pointed out, it is difficult to determine what activity is not strategic (JARZABKOWSKI et al. 2007:7). One approach to dealing with this problem is to focus on those activities that draw on strategic practices. Strategy is a particular type of activity that is connected with particular practices, such as strategic planning, annual reviews, strategy workshops and their associated discourses.

According to Jarzabkowski et al. (2007) to set the agenda for the study of strategy from a practical perspective it is necessary to answer five questions:

a) What is strategy? To answer this question one must know the concept of strategy and strategy-as-practice (SAP), that is defined as follows: "includes the actions, interactions and negotiations of multiple actors and the practical situations they are based on the performance of activities." Refers to "make the strategy" that is the construction of the flow of activity through the actions and interactions of multiple actors and practices in which they are based;

b) Who is the strategist? All the actors of the organization are involved in the implementation of strategies, not only the actors at the top of the pyramid, so the strategists are all those involved in implementing the strategy;

c) What do strategists do? This question can be answered through the report of the specific practices such as meetings, use of analytical tools, management processes, discursive forms and also the implications of these activities to the strategy-as-practice;

d) What does an analysis of strategists and their doings explain? This question is motivated by two challenges: the first is that, as the SAP has a strong empirical emphasis on how the strategy is built, the result can not be defined, and the question may arise: "so what?" In the second, SAP sets out the strategic activities of microlevel explanations providing a broadest sense, so that strategy research and practice also have consequences for wider strategic activity; "Strategy-as-practice research may, therefore, rise to the challenge of explaining outcomes that are consequential at more macro-levels of the firm and industry";

e) How can existing organization and social theory inform an analysis of SAP? The common concern of these studies is to explain some aspects of the nexus between praxis, practices and practitioners (WHITTINGTON, 2006) and its impact in meeting the social strategy. According to the authors "Strategy-as-practice, in common with much other organization theory, draws from the meta-theoretical principles of sociology, social psychology, anthropology and ethnomethodology, among others, to understand the construction of activity within organizations."

In summary, five aspects must be addressed in the ongoing challenges of research in strategy-as-practice. They are: the professionals, the link between practitioners and practice, 
theories of practice (which provide conceptual explanations of the social dynamics involved in implementing the strategy) and, finally, the methodological implications of different theoretical approaches.

More and more studies on SAP indicate that middle managers and lower-level employees are also important strategic actors. Additionally, these middle and operational-level employees typically lack of a formal strategy role, and practice research has focused upon the social, interpretative, linguistic and personal knowledge bases through which they shape strategy (REGNÉR, 2003; BALOGUN and JOHNSON, 2004, 2005; CURRIE and PROCTER, 2005; ROULEAU, 2005). Their actions and influence on strategy may be unintended at the firm level; they are significant for firm survival and competitive advantage. Hence, it is important to identify these actors as strategists, researching beyond top managers and incorporating and studying lower levels employees as strategic actors.

This approach and reasoning justify our research, give importance to a middle-up-down management (highlighting the role of the middle manager) and to an integrative strategy formation process in the organization, as a way of getting the strategy working out all around. This approach also refers to the idea of having strategy in all actions, and having all persons thinking strategically (TREGGOE and ZIMMERMAN, 1979); and this way of doing strategy can be adopted when we consider the roles of middle managers as the strategists that can shape and permeate strategy through all organizational levels (ROULEAU 2003; VAARA et al, 2004; MANTERE, 2005, BALOGUN and JOHNSON, 2004, 2005; AMBROSINI et al, 2007).

Hence, taking into consideration the different studies analysed and the different typologies revised, we state the following propositions to check them out in the empirical study:

Proposition 1: An integrative strategy formation process takes place throughout an equilibrium among the strategic variables rationality, involvement and vision, with a distinctive presence of emergent processes, more development of involvement (in detriment of a high level of rationality) and through a middle-up-down management. Proposition 2: Middle manager is the key part and the facilitator of the success of an integrative strategy formation process.

Proposition 3: Strategy as practice takes place through a middle-up-down management and it is characterized by combining in a balanced way rationality and emergence that is translated into higher levels of commitment of the agents in the process.

\section{METHODOLOGY}

We use a qualitative methodology, applying the method of single case study (EISENHARDT, 1989) since this technique enables the bundling of a significant number of data (YIN, 2005). The case study can be defined as a research strategy that is characterized by studying the phenomena as a dynamic process within its real context using multiple sources of evidence, in order to explain the observed phenomenon globally and taking into account all its complexity (YIN, 1994). Considering the goal, this research is characterized as explicative, as it aims to investigate how strategy formation process develops, answering some how and why questions.

The main reason for the selection of this case is sustained in the intentionality of the case (EISENHARDT, 1989). The case is, following Yin (1994), a critical case for studying the variables analysed, that is, those variables characterising the strategy formation process (rationality, vision and involvement) and the roles and characteristics of the middle manager (championing, synthesising, facilitating and implementing). Moreover, other reasons have also guided the selection process: the need to guarantee the viability of the study (the University permitted the study, and this fact responds to the criteria of accessibility/convenience); also, we had the possibility of analysing an organization that could offer the opportunity to learn and to have new perspectives about the topic we were focused on. That fact could let us to extend (EISENHARDT, 1989) or verify (YIN, 1993) the existing theory. In addition, it was selected a public service organization (education - University of Valencia) with a great size, which guarantees a certain level of development of the strategic process.

The unit of analysis is the organization, considered as an open system, focusing on the analysis of the strategy formation process and studying how rationality and emergence are combined in this process [ (by vision that integrates ideas that emerge in a certain order, influenced by the rational and planned processes, according to the level of participation and formalisation of these processes (HART, 1992)]. We used a multilevel analysis focusing on middle management activities in strategy processes and practices (formulation and implementation that include the different roles and characteristics of the middle managers and the way in which things are managed in different levels.

Sources of evidence and data collecting procedures: We used three different techniques: (i) in-depth interviews with different members of the organization - the inter- 
views were open and flexible, through a semi-structured questionnaire. We developed a pre-planning of the interviews, with a timetable including the duration, level in the hierarchy, and instruments used in the case (Exhibit 1).

The major parts of the interviews were developed in the managerial level, as they had information both of strategic issues and of work characteristics. Interviews were recorded, in order to better analyse its content. This fact facilitated us the triangulation of the information; (ii) document analysis referred to the organization studied (we analysed the documents elaborated by the organization itself, that is, the strategic plan, flow charts, job description, promotional material, different economic and general reports, web information, internal publications and other published information in the academic journals and newspapers); (iii) Direct observation (we observed how the process took place, and also the different relationships among sections analysing its culture and the way of doing things in situ. We visited the organization facilities, and spent time observing how the different processes related to the activities went on in the diverse departments. This fact let us confirm many questions mentioned in the interviews or in the analysed documents. We emphasize that the triangulation of data was ensured by using the sources cited avoiding the potential bias from a single source of data and assisting in the construction of more complete and accurate analysis by converging sources of evidence (EISENHARDT, 1989; YIN, 1994).

To obtain and study evidences from the data analysis we adopted the techniques of behavior patterns examination (BPE) and integrated pattern matching (PM) (PÉREZ-
AGUIAR, 1999). These techniques consist in comparing the real phenomenon with a pattern of behavior. Therefore, we analysed in the case the strategy formations process, the roles of middle management and the strategic practices through the analysis of the variables reviewed in literature (Exhibit 2).

In summary, we compared the facts, behavior and circumstances included in the theoretical propositions with the facts, behavior and circumstances (analysing the set of actions involved in the process, how environment is, day-to-day organization - real phenomenon) in the case observed.

We specified the variables used in the data collecting process, enabling the process of analysis and generation of results (Exhibit 2).

\section{ANALYSIS OF RESULTS}

In this section we are going to present the joint analysis of the information obtained in the case alongside the discussion and the comprobation of the considered propositions, looking for patterns that could explain the explored issues or the analysed variables behavior.

The case studied was the University of Valencia (UV). UV was founded in 1499 with the name of "General Study of Valencia" and was initially focused on the studies of medicine, humanities, teology and law; today it is a modern European University, and it is open to the different branches of knowledge, research, and culture.

University of Valencia is a public institution, with different rights protected and recognized by the Spanish

\section{Exhibit 1- Schedule of visits and interviews}

\begin{tabular}{|l|c|l|l|}
\hline DATE & DURATION & \multicolumn{1}{|c|}{ RESPONSIBLE } & \multicolumn{1}{|c|}{ INSTRUMENT } \\
\hline 06.04 .2007 & $1 \mathrm{~h}$ & $\begin{array}{l}\text { Responsible for the Planning and Analysis Service } \\
\text { (middle-manager) }\end{array}$ & Interview \# 1 semi-structured \\
\hline 06.08 .2007 & $1.5 \mathrm{~h}$ & $\begin{array}{l}\text { Vicedean of European Convergence and Quality } \\
\text { (top manager) }\end{array}$ & Interview \# 2 semi-structured \\
\hline 06.11 .2007 & $2 \mathrm{~h}$ & Dean (top Manager) & Conference "University 2007" \\
\hline 07.11 .2007 & $1 \mathrm{~h}$ & $\begin{array}{l}\text { Responsible for the Group for External Analysis } \\
\text { (middle-manager) }\end{array}$ & Interview \# 3 semi-structured \\
\hline 07.12 .2007 & $6 \mathrm{~h}$ & General Meeting Components (all levels) & Observation \\
\hline 09.07 .2007 & $2 \mathrm{~h}$ & Reseacher (middle-manager) & Interview \# 4 semi-structured \\
\hline 09.07 .2007 & $2 \mathrm{~h}$ & Lecturer (middle-manager) & Interview \# 5 semi-structured \\
\hline 09.07 .2007 & $1 \mathrm{~h}$ & Administrative Personnel (operational level) & Interview \# 6 semi-structured \\
\hline
\end{tabular}


Constitution and other Laws. Moreover, the UV, as a public service, has the mission of teaching and spreading the necessary knowledge in order to facilitate an adequate learning process, a correct professional or artistic training for their future professional development, and the achievement of the corresponding academia titles. The final objective of this institution is the continuous updating of knowledge and continuous training of their teaching staff (and also of the staff belonging to other teaching levels) - University of Valencia has experimented an important process of transformation in the eighties, improving the quality of the teaching process and facilitating both basic and applied research, and the scientific and technological development.

A process of convergence in higher education is taking place nowadays in Europe. This process is one of the external factors affecting the decision process in the University. On the other hand the strategy formation process takes place in parallel with the formulation and implementation of the strategic planning process that is a strategic guide in the organization. The Strategic Plan is a strategic guide in the organization and is conducted involving all levels of organization. As the UV Dean says:

The University of Valencia needs a Strategic Plan in order to identify those key factors and goals that permit us to adapt to those changes and challenges that the environment requires. Together with that, the Strategic Plan will contribute to an improvement of the organization, and to a better social perception of the University and its activities. Summarising, the University of Valencia needs to define the future instead of reacting to it. The Strategic Plan is a tool that helps us to design the desired future, with methodological rigorousness in order to plan the implementation of the programmed actions and the required resources, and to evaluate the execution, changing and adapting the objectives when necessary. The main objective of this Strategic Plan is to give the management team (understanding it as people and organizations with managerial responsibilities) an important tool that facilitates the elaboration of a shared vision and future, positive and hopeful, but valuing the tradition and history of the institution.

Quoting the words of the Vice-Dean of Quality and European Convergence:

The participation in the process of the elaboration of strategic plan has been very important; the process was open to the whole university community and everyone could express their opinion about the document in progress that was being elaborated. The most specialist work creating and developing the strategic lines of the plan was done by internal groups of the University, and they were formed by lecturers, administrative personnel and students, depending also on the content of each strategic line. The president of the Committee for the Development of the Plan (Vice-Dean of Quality and

Exhibit 2 - Description of variables analyzed

\begin{tabular}{|c|c|c|}
\hline VARIABLE & DESCRIPTION & CONCEPT \\
\hline \multirow{3}{*}{ V1 } & \multirow{3}{*}{ Strategy } & V1.a: Rationality: Formalisation and analysis in the decision-making process. \\
\hline & & V1.b: Vision: value transmission. \\
\hline & & V1.c: Involvement: participation level (distributed authority), and decision involvement. \\
\hline \multirow{4}{*}{ V2 } & \multirow{4}{*}{$\begin{array}{l}\text { Middle Manager } \\
\text { Characteristics }\end{array}$} & $\begin{array}{l}\text { V2.a: Championing alternatives: guiding and promoting, defending, presenting alternatives to } \\
\text { top management (defender) }\end{array}$ \\
\hline & & $\begin{array}{l}\text { V2.b: Synthesising information: categorising ideas, selling these ideas to top management, } \\
\text { combining and applying the information, synthesising it; }\end{array}$ \\
\hline & & $\begin{array}{l}\text { V2.c: Facilitating adaptability: protecting and promoting adaptation activities, sharing informa- } \\
\text { tion, guiding the adaptation, facilitating learning; }\end{array}$ \\
\hline & & $\begin{array}{l}\text { V2.d: Implementing deliberate strategy: implementing, reviewing and adjusting, motivating and } \\
\text { inspiring as a coach. }\end{array}$ \\
\hline V3 & Strategizing & $\begin{array}{l}\text { V3: Strategic specific practices such as meetings, use of analytical tools, management proces- } \\
\text { ses and discursive forms of activities to the strategy-as-practice }\end{array}$ \\
\hline
\end{tabular}


European Convergence) has visited every group, organization and institute in the University to present the Plan. Those visits were mainly asked by the students of the different university degrees.

According to the Dean:

Defining the product and the service of the UV is a very complex task. If we say that the UV produces degrees, we should ask what degrees? Which types of degrees? There are official degrees, particular degrees, and other studies that are not degrees but diploms; also, UV produces basic and applied research, generates knowledge transfer, culture. That is, there is not a product or a service, but a diversity of products and services that emerge from the heterogeneity of the organization. However, and for all those reasons, we can say that the main output of the University is teaching and researching. And the different services of the organizational structure of the UV act as a coordination link that reinforces the main designed activities.

According to their words and to the documents (mainly strategic plan) the analysis of the strategy formation process occurs in both ways: it comes determined both from the Dean and his staff and from the participation of different levels of institution.

Here on we summarise and analyse the research questions and its corresponding propositions, trying to answer them with the evidences found in the case.

Considering Q1: How does the strategy formation process take place; particularly, considering the relevance of the integrative perspective and the use of the variables -- rationality, involvement, and vision?

We established that: P1: An integrative strategy formation process takes place throughout an equilibrium among the strategic variables rationality, involvement and vision, with a distinctive presence of emergent processes and more development of involvement (in detriment of a high level of rationality) and through a middle-up-down management.

Taking into account the evidences found for the variables rationality (minimum formalisation of the processes, more consensual decision-making), vision (spread all over the organization, in folders, meetings, web page and actions involving the external community), and involvement (different levels take part on decision-making, participate in the meetings, be involved in different projects in research, teaching or extension actions to community), we have found that UV is developing an integrative strategy formation process, and this process obtains positive results in the organization being translated in a middle-up-down management.

According to the Responsible of the Planning and Analysis Service:
Although there is a fit between the strategic process and the different types of activities or works managed (differ- ent professions/careers, research, and bureaucratic works), the fit will be greater with a higher level of rationality. Rationality is limited by the politic processes that take place in this kind of organizations.

As a result, we can say that this proposition is confirmed, results could, indeed, improve with more rationality, with less influence of the politic process. This way, the level of manager's intention influence in the organization should be greater. Although, the mid-level of dynamism of the environment fits with a bottom-up approach (less rational)

Considering Q2: What is the relationship between an integrative strategy formation process and the middle management roles?

We established that P2: Middle manager is the key part and the facilitator of the success of an integrative strategy formation process.

Here we adopted Floyd and Wooldridge (2000) typology to analyse the role played by middle manager (coordinators, people in charge of departments or centres and at the same time they are teachers, researchers) in doing strategy. They are the agents that are developing the major works (classified as more innovative and creative) that require great levels of knowledge (teachers, researchers); consequently, they have the necessary abilities to participate in the decision-making processes and as a result, they are more involved in the strategic process.

We could observe that, for example, when they participated in the most important meeting in which they represented the group championing and synthesising information to the Dean to close and decide (approve or not) strategic planning; and soon after the meeting when they should transmit that decision to the whole group facilitating and implementing the strategic planning. They have space to participate, to express their thoughts, agreements and disagreements, confirming the studies of Floyd and Lane (2000).

Those roles of the middle manager took place clearly in the case of the UV. Taking all these issues into account we can say that the proposition is confirmed atUV.

Finally, considering Q3: How is strategy-as-practice related to the different roles of middle management? 
We established that P3: Strategy as practice takes place through a middle-up-down management and it is characterized by combining in a balanced way rationality and emergence that are translated into higher levels of commitment of the agents (middle managers) in the process.

We have considered specific strategic practices such as meetings promoted to define the different phases of the strategic plan; the use of analytical tools as those ones used by the responsible for the Planning and Analysis Service (reports, informational tables and maps); management processes (e.g. departments responsible for the doctoral registration and procedures or establishment of budgets) and discursive forms of activities to the strategy-as-practice during the implementation of strategies defined in the general meeting.

In the meetings, the mission and vision of the University is transmitted, as well as in the speeches of the Dean and his staff. The formalysed strategy is translated by the strategic planning that was discussed and constructed involving different levels and departments and that is implemented throughout middle management. During the implementation, the participation (of teachers, researchers, lecturers and administrative staff) is noticed in all process, where there is space for emergence, there are department meetings that teachers, researchers and employees in general can take part and contribute to what is happening in different situations (all those typically of this kind of organization -JARZABKOWSKI, 2003) developing actions defined in the plan, putting the strategy in practice. In this context, Practices is defined by Jarzabkowski et al. 2007, p. 9, as:
Routinized types of behavior which consist of several elements, interconnected to one another: forms of bodily activities, forms of mental activities, 'things' and their use, a background knowledge in the form of understanding, know-how, states of emotion, and motivational knowledge.

Analysing the case in depth we realise that when the organization permits and incentivates a greater degree of participation, strategy-as-practice approach occurs in all levels and a middle-up-down management appears (in the figure of department heads, some researchers), mainly when there is a specific goal (synthesising information or implementing strategic planning, for example). We could notice that when the organization put more emphasis in its communication (communicating strategy), it obtains a greater degree of involvement of the agents (when implementing strategic plan all over the UV). Rationality appears throughout the meetings established (scheduled) and the emergence appears in the content discussed in the meetings. Thus, we can confirm this proposition.

We synthesise the analysis of variables, summarising variables concepts adopted (Exhibit 2) and main evidences found in the data analysis of the case (UV) for each of the selected variables (Exhibit 3).

Despite its age, UV is in an important development stage. The environment of the UV is more competitive day after day, but the institution has a relevant and secure position in it. The achievement of a better fit among the analysed variables (that is, an increase of rationality with

\section{Exhibit 3 - Variables evidences at UV}
V1.a: Rationality: Mid-level of rationality in the decision-making process.
V1 Strategy
V1.b: Vision: Relevant and systematic value transmission.
V1.c: Involvement: High Levels of participation and involvement in decisions (department mee- tings corum),
V2.a: (+) Defender: systematically presents alternatives to top management (Centres level);
Middle $\quad$ V2.b: $(+)$ Synthesiser: systematically sell ideas to top management (Dean);
V2 Manager Characteristics
V2.c: (+) Facilitator: Share information received, task forces (department levels);
V2.d: (+) Implementing: High level of project and research groups as well as mid-level in departments.
V3 Strategizing
V3: General meetings; External environment analysis by the expertises from the management de- partment; management processes and discursive forms of activities to the strategy-as-practice 
less importance of the political processes) would permit the UV to achieve better internal and external results.

The triangulation of data collected allows us to confirm the theoretical propositions (answering the research questions) in an extent that we consider appropriated (Table 1).

Considering the results obtained in this research we can summarise them in the following new proposition that can be the basis of future hypothesis and quantitative research:

New proposition: The involvement of middle manager (synthesising, defending or championing, facilitating, and implementing) has a special relevance in the adoption of an integrative strategy formation process and can be the connection of Strategy Processes and Strategy Practices.

This new proposition intends to be a limited contribution to future study comprising strategy in a day-by-day activities, considering the common activities that are developed on a daily basis in an organization as a result of a deliberated or emergent strategy that takes place inside the organization, and which are put into action.

\section{CONCLUSIONS: LIMITATIONS AND FUTURE WORK}

Taking into consideration our goal in this research that was to analyse the relationship between the integrative strategy formation process and the roles of middle management under the strategy-as-practice perspective, we can say that it has been reached.

University develops an integrative strategy formation process and confers to middle management a very important role that is extended all over the university. Furthermore we can stand that the strategy is formed through the different levels of the organization; this way of doing strategy is in line with the perspective of strategy as practice suggested by Jarzabkowski (2003, 2004, and 2008).

We believe that middle manager develops a very important role in the integrative strategy formation process, acting as an agent between top and bottom levels, even being able to intercede and change organization directions by inserting their organization practical perspectives. This positioning can characterize or connect the different strategic practices in the organization.

Nevertheless we must point out that the main limitations of the study are those belonging to the number of cases (unique case) studied. However, we have tried to reduce this limitation through the use of a case protocol, specified in every step of the study. Moreover, the theoretical review reinforced the established logic, and permitted a greater degree of objectivity; on the other hand, we triangulated the different data sources and established evidences through the different data collecting techniques.

On the other hand, results of the case analysis cannot be generalised (as we can do with other quantitative techniques using statistic analysis). Yin (1993) establishes that the results of the case analysis can be generalised through theoretical propositions, but not to a population.

As a future research line of this work, we intend to develop a longitudinal study of the same case, in order to confirm if the established proposition is consistent for a specific period of time, adopting the narrative methodology analysis suggested by Fenton and Langley (2008); also, we should identify and consider new variables. Additionally, we should analyse in depth how the different types of work developed in an organization affect the strategy and how they could facilitate that strategizing occurs in the whole organization. Another study that can be developed from this one is a comparison to a Brazilian University.

\section{REFERENCES}

AMBROSINI, V, BOWMAN, C; BURTON-TAYLOR, S. Inter-team coordination activities as a source of customer satisfaction. Human Relations, v. 60 , n. 1, p. $59-98,2007$

ANDERSEN, T. J. Strategic planning, autonomous actions and corporate performance. Long Range Planning, v. 33, n.2, p. 184-200, 2000.

ANDERSEN, T. J. Integrating the strategy formation process: an international perspective. European Management Journal, v. 22, n. 3, p. 263-272, 2004a.

Table 1 - Relationship among research questions, variables, propositions, and results

\begin{tabular}{|c|c|c|c|}
\hline RESEARCH QUESTION & VARIABLES & PROPOSITIONS & RESULT \\
\hline Q1 & V1 & P1 & Confirmed \\
\hline Q2 & V2 & P2 & Confirmed \\
\hline Q3 & V3 & P3 & Confirmed \\
\hline
\end{tabular}


ANDERSEN, T. J. Integrating decentralized strategy making and strategic planning processes in dynamic environments. Journal of Management Studies, v. 41, n. 8, p. 1271-99, 2004b.

ANSOFF, I. Corporate strategy. New York: McGraw-Hill, 1965.

ANSOFF, I. The emerging paradigm of strategic behavior, Strategic Management Journal, v. 8, n. 6, p. 501-515, 1987.

BALOGUN, J. From blaming the middle to harnessing its potential: creating change intermediaries, British Journal of Management, v. 14, n.1, p. 69-83, 2003.

BALOGUN, J; JOHNSON, G. Organizational restructuring and middle manager sensemaking. Academy of Management Journal, v. 47, n. 4, p. 523-549, 2004.

BALOGUN, J; JOHNSON, G. From intended strategies to unintended outcomes: the impact of change recipient sensemaking. Organization Studies, v. 26, n. 11, p. 1573-1601, 2005.

BREWS, P. J; HUNT, M. R. Learning to plan and planning to learn: resolving the planning school/learning school debate. Strategic Management Journal, v. 20, n. 10, p. 889-913, 1999.

BURGELMAN, R. A. A model of the interaction of strategic behavior, corporate context, and the concept of strategy. Academy of Management Review, v. 8, n. 1, p. 61-70, 1983a.

BURGELMAN, R. A. A process model of internal corporate venturing in the diversified major firm. Administrative Science Quarterly, v. 28, n. 2, p. 223-244, 1983b.

BURGELMAN, R. A. Intraorganizational ecology of strategy making and organizational adaptation: theory and field research. Organization Science, v.2, n. 3, p. 239-262, 1991.

BURGELMAN, R. A. A process model of strategy business exit: implications of an evolutionary perspective on strategy. Strategic Management Journal, v. 17, Special Issue, 193-214, 1996.

BURGELMAN, R. A. Strategy as a vector and the inertia of co-evolutionary lock-in. Administrative Science Quarterly, v. 47, n. 2, p. 325-57, 2002.

COLLIER, N, FISHWICK, F; FLOYD, S. W. Managerial involvement and perceptions of strategy process. Long Range Planning, v. 37, n. 1, p. 6783, 2004.

CURRIE, G; PROCTER, S. J. The antecedents of middle managers' strategic contribution: the case of a professional bureaucracy. Journal of Management Studies, v. 42, n. 7, p. 1325-1356, 2005.

EISENHARDT, K. M. Building theories from case study research. Academy of Management Review, v. 14, n. 4, p. 532-550, 1989.

ELBANNA, S. Strategic decision-making: Process perspectives. International Journal of Management Review, v. 8, n. 1, p. 1-20, 2006.
FENTON, C; LANGLEY, A. Strategy as practice and the narrative turn. Les cahiers de Recherche du GéPS, v. 2, n. 6, May 2008. Disponível em http://web.hec.ca/geps/ FentonLangley080528_narrative\%20turn.pdf Acesso em 20.05.2009.

FARJOUN, M. Towards an organic perspective on strategy. Strategic Management Journal, 23, p.561-594, 2002.

FLOYD, S. W; LANE, P. J. Strategizing throughout the organization: managing role conflict in strategic renewal. Academy of Management Review, v. 25, n. 1, p. $154-177,2000$.

FLOYD, S. W; WOOLDRIDGE, B. Middle management involvement in strategy and its association with strategic type: a research note. Strategic Management Journal, 13, p. 153-167, 1992.

FLOYD, S. W; WOOLDRIDGE, B. Dinosaurs or dynamos? Recognizing middle management's strategic role. Academy of Management Executive, v. 8, n. 4, p. 47-57, 1994.

FLOYD, S. W; WOOLDRIDGE, B. Middle management's strategic influence and organizational performance. Journal of Management Studies, v. 34, n. 3, p. 465-85, 1997.

FLOYD, S. W; WOOLDRIDGE, B. Building strategy from the middle: reconceptualizing strategy process. Thousand Oaks, CA: Sage, 2000

HAMBRICK, D. C. Environment, strategy and power within top management teams. Administrative Science Quarterly, v.26, n. 2, p. 253 276,1981 .

HAMBRICK, D. C. The top management team: key to strategic success California Management Review, v. 30, n. 1, p. 88-108, fall 1987.

HAMBRICK D. C; MASON, P. A. Upper echelons: the organizations as a reflection of its top managers. Academy of Management Review, v.9, n.2, p. 193-206, 1984.

HAMEL, G; PRAHALAD, C. K. Competing for the future. Harvard Business Review, Jul.-Ago, p. 122-128, 1994.

HART, S. L. An integrative framework for strategy-making processes. Academy of Management Review, v. 17, n. 2, p. 327-351, 1992.

HENDRY, J. Strategic decision making, discourse, and strategy as social practice. Journal of Management Studies, v. 37, n. 7, p. 955-977, 2000.

HICKSON, D. J; MILLER, S. J; WILSON, D. C. Planned or prioritized? Two options in managing the implementation of strategic decisions. Journal of Management Studies, v. 40, n. 7, p. 1803-1836, 2003.

JARZABKOWSKI, P. Strategic practices: an activity theory perspective on continuity and change. Journal of Management Studies, v. 40, n. 1, p. $23-55,2003$

JARZABKOWSKI, P. Strategy as practice: recursiveness, adaptation, and practices-in-use. Organization Studies, v. 5, n. 4, p. 529-560, 2004. 
JARZABKOWSKI, P. Shaping strategy as a structuration process. Academy of Management Journal, v. 51, n. 4, p. 621-650, 2008.

JARZABKOWSKI, P; BALOGUN, J; SEIDL, D. Strategizing: the challenges of a practice perspective. Human Relations, v. 60, n. 1, p. 5-27, 2007.

JARZABKOWSKI, P; FENTON, E. Strategizing and organizing in pluralistic contexts. Long Range Planning, v. 39, p. 631-648, 2006.

JARZABKOWSKI, P; SEIDL, D. The role of meetings in the social practice of strategy. Organization Studies, v. 29, n. 11, p. 1391-1426, 2008.

JARZABKOWSKI, P; SILLINCE, J. A rhetoric-in-context approach to building commitment to multiple strategic goals. Organization Studies, v. 28, n. 11, p. 1639-1665, 2006.

JARZABKOWSKI, P; SPEE, Andreas Paul. Strategy-as-practice: a review and future directions for the Field. International Journal of Management Reviews, v. 11, n. 1, p. 69-95, 2009.

JARZABKOWSKI, P; WHITTINGTON, R. Directions for a troubled discipline: strategy research, teaching, and practice-introduction to the dialog. Journal of Management Inquiry, v. 17, n. 4, p. 266-268, 2007.

JARZABKOWSKI, P; WHITTINGTON, R. A strategy-as-practice approach to strategy research and education. Journal of Management Inquiry, v. 17, n. 4, p. 282-286, 2008.

JARZABKOWSKI, P; WILSON, D. C. Top teams and strategy in a UK University. Journal of Management Studies, v. 39, n. 3, p. 355-381, 2002.

JOHNSON, G; MELIN, L; WHitTingtON, R. Micro strategy and strategizing: towards an activity-based view. Journal of Management Studies, v. 40, n. 1, p. $3-22,2003$

LANE, D; MAXFIELD, R. Strategy under complexity: fostering generative relationships. Long Range Planning, v. 29, n. 2, p. 215-231, 1996.

MANTERE, S. Strategic practices as enablers and disablers of championing activity. Strategic Organization, v. 3, n. 2, p. 157-284, 2005.

MANTERE, S. Role expectations and middle manager strategic agency. Journal of Management Studies, v. 45, n. 2, p. 294-316, 2008.

MASON, R. B. The external environment's effect on management and strategy: a complexity theory approach. Management Decision, v. 45, n. 1, p. 10-28, 2007.

MINTZBERG, H. The nature of managerial work. New York: Harper and How, 1973

MINTZBERG, H; WATERS, J. A. Of strategies, deliberate and emergent. Strategic Management Journal, v. 6, n. 3, p. 257-272, Jul-Sept. 1985.

NONAKA, I. Toward middle-up-down management: accelerating information creation. Sloan Management Review, v. 29, n. 3, p. 9-18, 1988.

NONAKA, I. A dynamic theory of organizational knowledge creation. Organizational Science, v. 5, n. 1, p. 14-37, 1994.

PAPPAS, J. M; WOOLDRIDGE, B. Middle managers' divergent strategic activity: an investigation of multiple measures of network centrality. Journal of Management Studies, v. 44, n. 3, p. 323-341, 2007.

PÉREZ-AGUIAR, W. El estudio de casos. In: SARABIA, F J. (Ed) Metodología para la investigación en marketing y dirección de empresas. Madrid: Pirámide, 1999.

PORTER, M. Competitive strategy, techniques for analyzing industries and competitors, New York: Free Press, 1980

QUINN, J. B. Strategic change: logical incrementalism. Sloan Management Review, v. 20, n. 1, p. 7-21, 1978.

REGNÉR, P. Strategy creation in the periphery: inductive versus deductive strategy making. Journal of Management Studies, v. 40, n. 1, p. 57-82, 2003

REGNÉR, P. Strategy-as-practice and dynamic capabilities: steps towards a dynamic view of strategy Human Relations, v. 61, n. 4, p. 565-588, 2008

ROULEAU, L. Micro-strategy as gendered practice: resisting strategic change through the family metaphor. European Group for Organization Studies, Copenhagen, under review, July 2003.

ROULEAU, L. Micro-practices of strategic sensemaking and sensegiving: how middle managers interpret and sell change every day. Journal of Management Studies, v. 42, n. 7, p. 1413-1441, 2005.

SCHATZKI, T. R. The sites of organizations. Organization Studies, v. 26, n. 3, p. 465-484, 2005.

SHRIVASTAVA, P; GRANT, J. Empirically derived models of strategic decision-making processes. Strategic Management Journal, v. 6, n.2, p. 97-113, 1985.

TREGOE, B. B; ZIMMERMAN, J. W. Strategic thinking. Management Review, Feb. p. 8-14, 1979.

WEICK, K. E. Enacted sensemaking in crisis situations, Journal of Management Studies, n. 24, p. 305-317, 1989

VAARA, E, KLEYMAN, B; SERISTO, H. Strategies as discursive constructions: the case of airline alliances. Journal of Management Studies, v. 41, n. 1, p. 1-35, 2004.

WHITTINGTON, R. Completing the practice turn in strategy research. Organization Studies, v. 27, n. 5, p. 613-634, 2006.

WhitTingtON, R; MOlLOY, E; MAYER, M; SMITH, A. Practices of strategising/organising. Long Range Planning, v. 39, n. 6, p. 615-629, 2006

WOOLDRIDGE, B; FLOYD, S. The strategy process, middle management involvement, and organizational performance. Strategic Management Journal, v. 11, n. 3, p. 231-241, 1990.

YIN, R. K. Applications of case study research. Newbury Park, CA: Sage, 1993

YIN, R. K. Case study research: design and methods. 2. ed. Thousand Oaks, CA: Sage, 1994. 